UDK: 811.124'36(035) „1832“ Matić, A. Izvorni znanstveni članak Primljen 22. X. 2019.

Katica Krešić

Filozofski fakultet Sveučilišta u Mostaru

katica.kresic@ff.sum.ba

\title{
GRAMATIKA AMBROZA MATIĆA (1832.)
}

\section{Sažetak}

Godine 1832. u Osijeku je objavljena Knjixica Rucsna, latinska gramatika bosanskoga franjevca Ambroza Matića. Ambroz Matić predavao je latinski jezik i matematiku u Kraljevoj Sutjesci te je za nastavne potrebe sastavio jedan aritmetički udžbenik i latinsku gramatiku koja je pisana hrvatskim jezikom. U radu se promatra sadržajna koncepcija Knjixice kao pragmatične dopune Marijanovićevoj latinskoj gramatici. U hrvatskome se tekstu analiziraju slovopis i gramatičko nazivlje te se izdvajaju pojedina prijevodna leksička rješenja koja se nisu održala u hrvatskome jeziku.

Ključne riječi: latinska gramatika; hrvatski jezik; Ambroz Matić; slovopis; gramatičko nazivlje

\section{Uvod}

Pod hrvatskim gramatikama u širem smislu podrazumijevamo gramatike koje opisuju hrvatski jezik i one u kojima se strani jezik opisuje hrvatskim. ${ }^{1}$ Nova ricsoslovica iliricska Šime Starčevića (1812.) prva je gramatika hrvatskoga jezika pisana hrvatskim jezikom, bez supostavljanja

1 Usp. Branka Tafra - Anela MateljaK, „Mjesto Šitovićeve gramatike u povijesti hrvatskoga jezikoslovlja“, Zbornik o Lovri Šitoviću, Hrvatski studiji Sveučilišta u Zagrebu, Zagreb, 2009., str. 111. - 129. 
prema drugome jeziku. Do tada se ustrojstvo hrvatskoga jezika moglo spoznati iz gramatika u kojima se strani jezik opisivao hrvatskim. Te su dvojezične gramatike imale važnu ulogu u izgrađivanju hrvatskoga standardnog jezika, ali i važno mjesto u povijesti hrvatskoga školstva. „Učenici su, nema dvojbe, iz gramatika latinskog ne samo tijekom 17. i 18. stoljeća, nego i kasnije (pa čak i danas) mnogo naučili ili obnovili svoje znanje normativne gramatike hrvatskog jezika ${ }^{{ }^{\prime}}$.

O latinskim se gramatikama franjevaca Bosne Srebrene iz 18. i 19. st., koje su služile elementarnoj nastavi latinskoga jezika, u znanstvenoj i stručnoj literaturi mnogo pisalo, posebice o gramatikama Tome Babića i Lovre Šitovića ${ }^{3}$. Autori su tih gramatika bili svećenici koji su predavali latinski jezik u javnim ili privatnim samostanskim školama te su i na temelju svoga nastavničkog iskustva pripremali gramatičke priručnike za svećenički podmladak. U sadržajnoj je koncepciji tih djela zamjetna školska tradicija pisanja jezičnih udžbenika. Strani se jezik u tim gramatikama, kao i u onim talijanskim i nekim turskim čiji su autori bosanski i hercegovački franjevci, opisivao hrvatskim jezikom jer je to bio materinski jezik onih kojima su namijenjene. Počimaoci su se sa stranim jezikom mogli upoznati i usvajati ga s pomoću drugoga jezika, a to je, prema Danteu „quem sine omni regula nutrices immitantes accepimus“" . Takve gramatike uglavnom sadrže definicije, primjere i različita objašnjenja na hrvatskome jeziku.

2 Pavao Knezović, „Njegovanje hrvatskog u gramatikama latinskog jezika (17. i 18. st.)“, $\mathrm{Hr}$ vatski jezik u Bosni i Hercegovini - jučer i danas, Pedagoški fakultet Sveučilišta u Mostaru, Mostar, 2002., str. 68.

3 Tомо BAвIć, Prima grammaticae institutio pro tyronibus Illyricis accomodata, Venecija, ${ }^{1} 1712 .,{ }^{2} 1745$. , Lovro Šitović, Grammatica Latino- Illyrica ex Emmanuelis aliorumque approbatorum grammaticorum libris, iuventuti Illyricae studiose accommodata, Venecija, ${ }^{1} 1713 .,{ }^{2} 1742 .,{ }^{3} 1781$.

O navedenim gramatikama v. Dragutin RAGUž, „Hrvatska gramatička terminologija u dvjema preradbama Alvaresove latinske gramatike“, Filologija, br. 10., Zagreb, 1981., str. 97. - 125., Zbornik o Tomi Babiću, Gradska knjižnica „Juraj Šišgorić“ Šibenik - Hrvatski studiji Sveučilišta u Zagrebu, Šibenik - Zagreb, 2002. i Zbornik o Lovri Šitoviću, Hrvatski studiji Sveučilišta u Zagrebu, Zagreb, 2009.

4 Dante Alighieri, Nauk o pučkom jeziku - De vulgari lingua, Institut za hrvatski jezik i jezikoslovlje, Zagreb, 1998., 10-11. 
Bosanski franjevac, latinist, pjesnik i prevoditelj Ambroz Matić (1795. - 1849. $)^{5}$ objavio je 1832. godine u Osijeku gramatiku naslovljenu Knjixica Rucsna s'upravam koristnim i uveshtbanjem lasnim za mladiche latinski jezik ucseche, u bosanski izgovor sloxena. Riječ je o preradbi Grigelyeve gramatike ${ }^{6}$ kojoj su prethodile Marijanovićeve preradbe ${ }^{7}$ nastale jedno desetljeće prije Knjixice. U ovome se radu, uz sadržajnu koncepciju Knjixice, u hrvatskome tekstu analizira slovopis, gramatičko nazivlje te se izdvajaju pojedina prijevodna leksička rješenja koja se nisu održala u hrvatskome jeziku.

\section{O Knjixici Rucsnoj}

Gramatika obaseže 178 stranica sadržaja i četiri stranice predgovora. Autor je u predgovoru (Dobrovoljni shtiocse!) naveo važne obavijesti o svojoj gramatici. Iz tih uvodnih riječi doznajemo o njegovim uzorima,

5 Ambroz Matić rodio se u mjestu Blaževac (Pelagićevo) kod Modriče 1795. god., a umro je 1849. god. u Garevcu (Modriča). Školovao se u Hrvatskoj i Ugarskoj. Filozofiju i teologiju završio je u Požegi. Predavao je latinski jezik i matematiku u Kraljevoj Sutjesci. Za gramatičke škole u BiH napisao je aritmetički udžbenik (Racsun za pervu i drugu godinu shkulsku iz latinskog u bosanski jezik ..., Osijek, 1827.) i latinsku gramatiku (Knjixica Rucsna s'upravam koristnim $i$ uveshtbanjem lasnim za mladiche latinski jezik ucseche, u bosanski izgovor sloxe$n a$, Osijek, 1832.). Udžbenik za poučavanje računstva prijevod je prvoga dijela latinskoga izvornika mađarskoga matematičara Pála Makóa. Matić je pisao poeziju na latinskome i hrvatskom jeziku, a posebno je bio poznat po prigodnicama koje je pisao istaknutim članovima svoga reda. Smatra se začetnikom autorizirane književnosti Bosanske Posavine. Uz fra Martina Nedića i fra Bonu Nedića najvažniji je posavski pisac 19. st. V. Mirko MarJanović, Leksikon hrvatskih književnika Bosne i Hercegovine od najstarijih vremena do danas, MH Sarajevo - HKD Napredak Sarajevo, Sarajevo, 2001., str. 176. O Matićevu aritmetičkom udžbeniku pisali su ANĐA VALENT - Ivica VuKović, „Računica fra Ambroza Matića: začeci metodike nastave matematike u Hrvata", Bosna franciscana, Sarajevo, god. XxIII. (2015.) br. 42., str. 95. - 109. i MARIJANA BorIĆ, „Hrvatski aritmetički udžbenik Ambroza Matića iz 1827. za gramatičke škole u Bosni“, Zbornik o Petru Bakuli, Hrvatski studiji Sveučilišta u Zagrebu, Zagreb, 2013., str. 449. - 462.

6 JózSef Grigely, Institutiones Grammaticae in usum scholarum grammaticarum regni Hungariae et adnexarum provinciarum, sv. I. - IV., Typis regiae universitatis Hungaricae, Budim, 1809.

7 StJepan Marijanović, Institutiones grammaticae latinae idiomate illyrico propositae ac ad usum iuventutis Provinciae Bosnae Argentinae compilata ..., Split, 1822. i Syntaxis linguae latinae iuventuti Provinciae Bosnae Argentinae accomodata, Apud Andream filiumque Santini, Venecija, 1823. 
sadržaju i namjeni priručnika, odnosu prema materinskome jeziku i sl. Naglašava nužnost pisanja udžbenika/priručnika u učionicama (shkulama) jer učenici ne mogu imati napretka „brez alata potrebitog; illiti knjiga, s'koimse vas njiovtrud oblakshaje, i mlogo zgodnii csini..." (IV). Nadalje pojašnjava zašto piše ovu gramatiku: „... ne iz ikakve druge izprazne sverhe, vech jedino lipom prilikom ostali Naroda ganut, i potaknut, za mladicha moji Domorodaca napredak, i vechu fajdu, uzeosam na me brigu, nastojanje, i trud, glede moga vlastitoga slaboga zdravja, maloumnoga razuma, moxe bitti nevieshtine u uzdignutju, i u uzdêrxanju mladicha menni vehoma texak, nepristojan, i nepodoban za izdati jednu knjixicu na svitlost za mladicha prizgodnu, koji I i II godine Grammatiku ucse (IV)“. U istome je dijelu naveo i poglavlja, koja su po ugledu na Grigelya, pisana u stihovima, vershima: Vershe I. od Prigibanja Imená, II. od Plemena isti imená, III. od Ricsi activi, IV. od Ricsi deponenti, V. od Pridstavaka. Ti su dijelovi pragmatičnoga karaktera, s tipičnim školskim, početničkim pristupom u usvajanju sadržaja kroz stihove. Slično Grigelyu Matić niže stihove, zatim navodi pravila na hrvatskome jeziku te primjere s hrvatskim prijevodom. Na Marijanovića se nekoliko puta poziva, odnosno upućuje čitatelja na tekst Marijanovićeve gramatike: „vidi Mar. Gram., 108“ (177), i „vidi gram. Marian.: 109“ $(177)^{8}$. Eksplicitno navodi da je riječ o dodatku: „... da svaki mladich imaduchi Grammatiku, i nju sistom u Ruki potrebuje imati ..." (V). Naslov je priručnika Matić obrazložio: „Koja knjixica toliko sudim, daje potrebita, i koristna, dasse u Grammatiki velik, il istinito brez velikog trúda, napredak zadobit nemoxe, niti imati, i zato imenujemju knjixica Rucsna ..." (V). Na kraju je predgovora autor podsjetio na mjesto, nadnevak i zanimanje: U Suttiski na 20. Veljacse 1828., / P. Ambroxa Matich, / Shkula Gram. Ucsitelj. Spomenuti nam podatci govore da je gramatika pisana četiri godine prije objavljivanja te da je autor predavao latinski jezik u gramatičkoj školi koja je djelovala u Kraljevoj Sutjesci.

Budući da je riječ o dopuni drugoga priručnika, sadržajna se struktura ove gramatike razlikuje od ostalih latinskih gramatika bosanskih

${ }^{8}$ S. MARIJANOVIĆ, Institutiones ... 
franjevaca. Dok Marijanović, kao i većina onodobnih gramatičara, pravilo postavlja kao odgovor na pitanje, za sve vrste riječi, njihove kategorije, podjele i sl., Matić navodi niz kratkih latinskih rečenica, sažeto pravilo na hrvatskome jeziku i dvojezične primjere. Opisan je samo dio morfologije: sklonidba i rod imenica, aktivni i deponentni glagoli i prijedlozi. Unutar svake tematske cjeline izdvajaju se uprave obchenske, tj. opća pravila (regulae generales) i uprave ossobite, odnosno posebna pravila (regulae particulares). ${ }^{9}$ Odstupanja od općih pravila slijede $\mathrm{s}$ primjerima u zasebnim cjelinama naslovljenim: Vade se iz ove uprave. Na stotinu su stranica kroz ukupno 268 kratkih pravila, obično u jednoj rečenici, s brojnim primjerima predstavljene imenice, i to sklonidba (1-55), rod imenica i odstupanja s obzirom na sklonidbeni tip (55-10o). Nema paradigmi ni kada razvrstava imenice po sklonidbenim tipovima, nego primjere pojedinih deklinacija kao predstavnike određenoga tipa objašnjava s obzirom na oblikotvorne morfeme, odnosno na što „izlaze“ padeži, tj. kakvo je njihovo „dovaršenje“. Matić izdvaja pojedine padeže i naglašava gramatičke morfeme prema sklonidbenome tipu, što se sadržajno dobro povezuje s Marijanovićevim imeničkim paradigmama. Pravila koja se odnose na imenice različito su predstavljena u Marijanovićevoj i Matićevoj gramatici. Matić je detaljniji od svoga uzora jer često jedno pravilo razlaže na nekoliko jednostavnijih (str. 5, 6, 8, $11-$ $16)^{10}$. Stupnjevito izložen sadržaj u temeljnome priručniku preko brojnih i raznolikih primjera kroz sažeta pravila u Knjižici, trebao je učenicima olakšati ovladavanje gramatičkom građom. Na dopunsko obilježje Knjixice autor upućuje nekoliko puta, što nas navodi na mogućnost usporedne uporabe navedenih priručnika. Tako Matić pravilima 27 i 28 dopunjuje Marijanovićeve primjere uz koje se navodi samo završetak imenica u akuzativu III. deklinacije: „Njeka imena vlastita Varosha, i sva gercska izhodecha na is u Nominativu jednost: â neimaju vishe sillaba u Genitivu nego u Nom. imadu takogjer Akusativ na im..." (11) ${ }^{11}$.

\footnotetext{
$9 \quad$ Umjesto uprave obchenske Marijanović ima regule obchenske, a umjesto posebnih pravila izdvaja zabilixenja.

1o Usp. S. Marijanović, Institutiones ..., str. 11. - 15. i A. Matić, n. dj., str. 8. - 26.

${ }_{11}$ Usp. S. Marijanović, Institutiones ..., str. 13. i A. Matić, $n$. dj., str. 11.
} 
Od ukupno pet poglavlja, sadržaj o gramatičkome rodu imenica obrađen je u jednome, zasebnom dijelu gramatike jer se autor detaljno zadržava na različitim kategorijama i vrstama imenica s obzirom na njihov završetak i značenje. U Marijanovića je, kao što je i najčešći slijed gramatičkoga sadržaja, kategorija roda definirana na početku gramatike. ${ }^{12}$

Za razliku od svojih prethodnika Matić uz pravila niže mnogo više latinskih primjera s prijevodom. Uz neka se pravila pojavljuju nizovi od 40 primjera s hrvatskim ekvivalentima. Stoga neke stranice nalikuju rječničkim, npr. 10, 12, 27, 143, 146 itd.

Na kraju je prvoga poglavlja izdvojen dio sadržaja o prilagodbi i sklonidbi grčkih imena (Nadometak III, str. 50) koja razvrstava prema završetcima te upućuje na Grygelya: „... vidi Grigelja pag. 94-106“ (55). Matićeva je gramatika „preradba jednoga dijela d r u g e sveske Grigelyeve, i to onoga, u kojemu su sadržani 'Versus Memoriales'“"13. Grigely nije navodio prijevod (zbog čega se ispričao) ${ }^{14}$, dok Matić to čini, pa na svojevrstan način dopunjuje Grigelya. To je uradio da bi tekst prilagodio domaćim učenicima.

Glagoli su, kao i imenice, obrađeni u dva poglavlja: Od Proshasti (praeteritis) Lexechi (supinis) Vrimena Riecsii (100-172) i Od Riecsi Deponenti (172-176). Promjene gramatičkih kategorija imenica i glagola u pravilima razvrstava s obzirom na promjene fonološkoga sastava riječi, odnosno na osnovi izhodećih slova $i$ sillaba.

Vladoje Dukat pronašao je primjere koji su preuzeti iz I. Grigelyeve sveske, npr. za V. deklinaciju. ${ }^{15}$ Zapazio je da je Matić unio i ponešto novo u odnosu na Grigelya, npr. Riecsi brez Supina, str. 109, a stihovi koje je naveo u tome poglavlju upućuju da ih je autor „uzeo iz kakvoga starijega izdanja Alvarezove ili slične kakve gramatike ${ }^{{ }_{16}}$.

U najkraćem, posljednjem poglavlju na samo šest stranica autor opisuje i oprimjeruje prijedloge.

\footnotetext{
12 Vidi M. Marijanović, $n$. $d j$., str. 3.

${ }_{3}$ Vladoje DuKat, „Hrvatske preradbe Grigelyevih Institutiones Grammaticae“, Rad JAZU, knj. 172., Zagreb, 1908., str. 41.

14 Usp. isto, str. 41.

15 Usp. nav. mj.

16 Usp. isto, str. 42.
} 
Kao i u Marijanovića, prijedlozi su razvrstani s obzirom na padežne oblike uz koje stoje. Uz prijedloge ne stoje prijevodni ekvivalenti, te autor upućuje na Marijanovića (177). Spomenute vrste riječi nisu definirane, a za imenice i glagole nisu navedene ni gramatičke kategorije.

Dukat Matićevu Knjixicu, prije svega u strukturnome smislu, dovodi u svezu sa školskim priručnikom fra Tomaša Mikloušića (1767. - 1833. ${ }^{17}$ : Syllabus vocabulorum grammaticae Emmanuelis Alvari in Croaticam linguam conversorum ( $\left.{ }^{1} 1796 .,{ }^{2} 1817.\right)$. Mikloušić je kao gimnazijski profesor (1795. - 1805.) poučavao mladiće latinski jezik i u to vrijeme pripremio udžbenik. Syllabus, koji obaseže 224 stranice, sadrži kajkavski prijevod latinskoga teksta. „Tu se, uz kratka pravila, u svakom dijelu daje mnogo primjera riječi svrstanih po rodu, po deklinaciji i konjugaciji glagola s njihovim preteritima i supinima. Svi su primjeri riječi predočeni

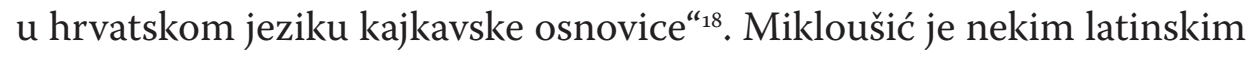
primjerima dodavao po nekoliko hrvatskih ekvivalenata. „Uz Mikloušićevu preradbu Syllabusa iz 1817., treba reći da je on već u prvom izdanju iste knjige, objavljene u Zagrebu 1796., proširio znatno originalni materijal i pohrvatio dosljedno latinsku terminologiju“19.

Razumljivo je da se u temeljnome udžbeniku i u njegovoj dopuni rabe obično isti gramatički nazivi. Gramatičke je nazive i toponime Matić uglavnom preuzeo od Marijanovića.

Budući da je riječ o dopuni koja nudi mnoštvo primjera, i tu vrstu sadržaja ograničava na imenice, glagole (supin i perfekt) i prijedloge, s neznatnim tekstom na hrvatskome jeziku, hrvatsko je gramatičko nazivlje,

${ }_{17}$ Tomaš Mikloušić rođen je u Jastrebarskome 1767. god. Teologiju je završio u Pešti 1790. Službu profesora gramatike latinskoga jezika počeo je obavljati u zagrebačkoj gimnaziji 1795., a od 1799. do 1805. predavao je i poetiku. Nakon toga je bio župnik u Stenjevcu i Jastrebarskome. Obrađivao je i prevodio kajkavske dramske tekstove.Umro je u Jastrebarskome 1833. god. Usp. Alojz Jembrin, „Tomaš Mikloušić i njegovo djelo“, Hrvatsko zagorje, Krapina, god. vir. (2001.) br. 2., str. 5. - 21.

Dukat navodi Matićev primjer koji se ne može razumjeti bez Mikloušićeve bilješke: „Abidos Varosh u Asii; od mileza naprav. (ovo je nerazumljivo, dok ne čitamo u Mikloušića: Abidos Várass Azie od Milezia napravlyen)“ (Dukat, nav. dj., 45).

18 Alojz JembriH, „Gramatičko nazivlje i leksička polivalencija u Mikloušićevu Syllabusu (1817.) “, Kaj, Zagreb, god. LI. (2018.) br. 1. - 2., str. 41. - 53.

19 Isto, str. 44. O sličnosti Mikloušićeva Syllabusa i Matićeve Knjixice vidi V. DuKaT, n. dj., str. 4. -46 . 
odnosno morfološko, vrlo skromno zastupljeno. Za nazive je padeža Matić uporabio internacionalizme, kao i njegovi prethodnici: Babić, Šitović i Marijanović, koji je navodio i domaća rješenja. Za gramatičku je kategoriju roda birao nazive pleme i spol. $\mathrm{U}$ istome pravilu često susrećemo oba naziva, npr.: "Slidecha imena je $\iint u$ mushkoga plemena, akoim dadesh cslanak hic, akoli haec je $\iint u$ xenskoga spolla" (61). Kada govori o srednjem rodu, češće se odlučuje za naziv pleme: „Koja imena imadu od Starine cslanak neznanoga spolla ... i je $\iint \mathrm{u}$ neutroga plemena" (61) ili u primjeru: „... koja imena u broju jedno trukomu na um dovershuju je $\iint u$ plem. neutr ..." (76).

Neki se nazivi razlikuju od onih koje je Marijanović navodio u svojoj gramatici: pleme neutro i samo neutro za srednji rod (Marijanović niednodrugo), ime obchensko (M. ime nazivajuche), ime prinoseche (M. zaimenak prinofljivi), pokrachenje illiti ispufchenje stihova (M. izrezanje, sinkopa). Za jezik je Matić izabrao nazive izgovor i jezik, a za glas nazivak, rjeđe glas.

Složeni (atributne sintagme) se nazivi obično pojavljuju usporedo s jednorječnim: broj jednoftruki/jednoftruki, broj vechoftruki/vechostru$k i$, ispu chenje slova/pokrachenje, pleme neutro /neutro, Riecsi Deponente/deponenta, smieshana imena/epicena, vrieme proshasto/praeterit i proshasto. $^{20}$

Nizovi gramatičkih naziva omogućavali su bogaćenje rječnika, usvajanje hrvatskoga nazivlja i lakše razumijevanje sadržaja u drugim priručnicima u kojima su ih učenici susretali.

Slijedi abecedni popis gramatičkih naziva u Matićevoj Knjixici.

broj jednoftruki

broj vechofruki

cslanak

deponenta

dionstvo

hotiuchi ime bistveno

ime brojljivo

ime nazivajuche

ime obchensko

ime prilagujuche

ime vlastito

${ }_{20}$ Među Matićevim matematičkim nazivima u aritmetičkome je udžbeniku čest prilog sadašnji: smalaksajuchi, uzimajuchi, uzmloxavajuchi itd., a u dvorječnim se pojavljuje kao odredbenica, npr. strane skupljajuche. Usp. M. Borić, $n$. dj., str. 458. 


$\begin{array}{ll}\text { jednoftruki } & \text { skup-slaganje } \\ \text { konjugacia } & \text { spol } \\ \text { konjugati } & \text { riecs } \\ \text { lexechi } & \text { rics csinecha } \\ \text { neutro } & \text { rics deponenta } \\ \text { pleme neutro } & \text { riecs saftavita } \\ \text { preterit } & \text { upadak } \\ \text { prigibanje } & \text { vechoftruki } \\ \text { prigibati } & \text { vrieme lexeche } \\ \text { pridstavak } & \text { vrieme proshasto } \\ \text { pristavak } & \text { vriemena riecsi } \\ \text { proshasto } & \text { zapovidajuchi }\end{array}$

sadashnje vrieme

Zavičajna toponimija u udžbenicima i priručnicima ima pragmatičan karakter, posebice kada je riječ o početnome učenju sadržaja. Od domaće toponimije u Knjixici susrećemo primjere: Bosna, Suttiska, Fojnica, Zennica, Derventa, Ilok, Vukovar, Sprecca, Krivaja, Ussora, Ukrina, Tinja, a od etnonima: Boshnjak, Hervvachanin i Slavonac..$^{21}$

Tražeći prikladne hrvatske jednakovrijednice za brojne latinske primjere, Matić je često birao neobična i jedinstvena leksička rješenja: brezposlenidnevi (odmor), çuddogled (drama), godishtapis (ljetopis), lagjavez (luka), naprieduzetje (teza), plashnja (strah), prigrish (grijeh), radhotiuchi (rado), raztjecsucha voda (tekućica), skup-slaganje (sintaksa), skupspravljanje (sinteza), slikotvorac (slikar), sloxnoglasje (glazba), sloxnogovora nauk (govorništvo, retorika), uredno govorenje (govorništvo, retorika), uredno ruku, i svega tiela mahanje (gestikuliranje) itd. ${ }^{22}$

Bez Marijanovićeva priručnika ova gramatika ne bi mnogo pomogla početnicima gramatičke škole I. i II. godine učenja. Spomenute se

${ }^{21}$ Od zavičajnih je toponima Marijanović uporabio: Zvornik, Sarajevo, Soli (Tuzla), Kreševo (125), Sutiska, Bosna, Livno (126). Domaći su toponimi među primjerima i u Mikloušićevu Syllabusu. Vidi V. Dukat, $n$. dj., str. 47.

22 Od spomenutih se primjera u Akademijinu rječniku nalazi riječ plashnja $\mathrm{AR} \mathrm{X} / 13$, a prema Matićevim leksemima slikotvorac i godishtapis likovi slikotvor AR XV/529 i godištopisanje, AR III/239. Riječ sloxnoglasje u Matića znači 'glazba', a u AR navode se značenja 'sklad glasova, harmonija, simfonija', AR XV/608. Preostali navedeni primjeri nisu zabilježeni u AR. 
gramatike strukturno razlikuju. Uz Marijanovićeve paradigme, podjele i definicije Matićeva kratka, usitnjena pravila bolje oprimjerena mogla su olakšati usvajanje latinske gramatike i rječnika. Nedostatak definicija vrsta riječi i gramatičkih kategorija svakako nije mogao omogućiti usvajanje gramatike hrvatskoga jezika. Međutim to ne umanjuje njezinu, prije svega pragmatičnu, ulogu koju je imala u vremenu u kojem je nastala. S Marijanovićevim dvjema gramatikama (1822. i 1823.) čini jednu sadržajnu cjelinu. Do narednih dviju preradba poslije Matićeve prošlo je duže razdoblje (Kunić, 1857. i Kraljević, 1863.). To je prvo djelo u nizu preradba bosanskih franjevaca naslovljeno hrvatskim jezikom, iako je hrvatskoga jezika u njemu malo.

\section{Slovopis}

Slavonski se slovopisni uzus u 18. st. širio izvan slavonskih prostora i bio je u uporabi sve do Gajeve slovopisne reforme. Ivo Pranjković smatra, zbog praktičnih i logičnih slovopisnih rješenja, „da ne bi bilo nikakve štete da je takav slovopis zadržan sve do danas ... On bi imao i nesumnjivih prednosti čak i u odnosu na aktualnu hrvatsku latinicu, pogotovo $\mathrm{s}$ informatičkoga stajališta" ${ }^{{ }_{23}}$. U tome su se inventaru izbjegavali podslovni i nadslovni znakovi, troslovi te dvostrukosti i višestrukosti. Prijedlog latiničkih slovopisnih rješenja fra Andrije Kujundžića u predgovoru latinske gramatike fra Stjepana Marijanovića naslovljen K. A. S. S. M. Z. X. pojavio se između objavljivanja dvaju djela u kojima je reformirani slovopis predstavio fra Augustin Miletić: Poçetak slovstva, Split, 1815. i prošireno izdanje istoga djela Istomaçegne stvari potrebitii nauka karstianskoga s predgovorom Opomena pisaocza Onim, kojise budu ovim Kgnixiczam sluxiti, Rim, 1828.

Matićeva je Knjixica nastala jedno desetljeće nakon pojave Kujundžić-Marijanovićeva lipopisanja (1822.). Lipopisanjem je u Bosnu

${ }^{23}$ Ivo PranjKović, „Latinička grafija budimskoga franjevačkog kruga i Kujundžić-Marijanovićevo 'lipopisanje'", Franjevačko spisateljstvo na hrvatskome jeziku, Hrvatska sveučilišna naklada, Zagreb, 2008., str. 79. Latinički slovopis budimskoga kruga, koji se brzo proširio i ustalio u Mađarskoj i Slavoniji, učvrstio je Stjepan Vilov u djelu Razgovor priateljski megju kerstianinom i ristianinom, Budim 1736. 
uneseno pisanje slova $l j$ i $n j$ (za foneme /l̦/ i /n,/) pod utjecajem slovopisa budimskoga kruga. ${ }^{24}$ Matić bilježi slovo ç za fonem /č/: çovik, naçin, obiçaj, poçetnik, sviraç, ali zadržava i dvoslov cs iz slovopisa budimskoga franjevačkog kruga: csastjenje, cse tit, csovik, csini, ocsev, vecsera, Veljac$s a$. U istim se riječima u nekoliko primjera pojavljuju oba načina pisanja navedenoga fonema: çiçak/csiçak, gerecski/Gerçka, Ricsi/riçju. Matić nije prihvatio bilježenje slogotvornoga $r$ s pratećim $a$, kako se prije njega uglavnom pisalo u Bosni (ar), ni Kujundžićevo rješenje är. ${ }^{25} \mathrm{Na}$ mjestu slogotvrnoga $r$ u Knjixici pronalazimo er: dervo, gerlo, germ, merkva, mersko, persa serce, terpeza, ternje.

Od Kujundžićeva slovopisa Matić odstupa kada je riječ o slovnome odrazu fonema /s/, bilježi ga slovom s: sillaba, sugjenje, persa, piesak,

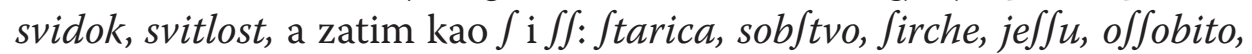

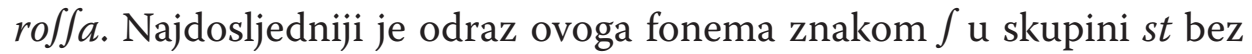

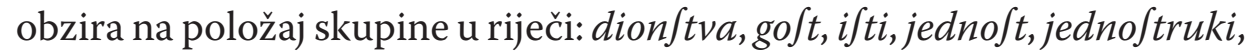

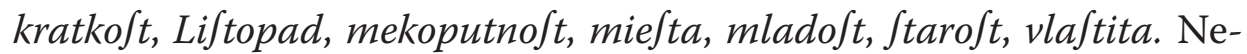
ujednačenosti nisu brojne: kratkoft, poniznost, svitlost/svitloft, miesto/ miesto.

Često Matić udvaja suglasnike da bi označio kvantitetu prethodnoga sloga: gnjidda, kappa, korra, kukka, nogga, nossi, oppanak, ranna, ribba, silla, slikka, sobba, xitto. Iako fonem /ź/ bilježi dvoslovom gj (megja, gragjanin), nailazimo i na odraze dj (medjumorje) i $j$ (meja, mejaš).

Odrazi su staroga jata $u$ Knjixici $i$ i ie. Zanimljivo je da se u pogledu zamjene jata u Matićevoj gramatici pojavljuju primjeri kao što su xier (žir), mier (mir), mierovati (mirovati), vier (vir). Dugo $i$ ispred $r$ dalo je

24 Usp. MARKo SAMARDŽıJA, „Doprinos budimskoga franjevačkog kruga oblikovanju tzv. slavonskoga slovopisa", Iz triju stoljeća hrvatskoga standardnog jezika, Hrvatska sveučilišna naklada, Zagreb, 2004., str. 14. - 19. i I. PRANJKOVIĆ, $n$. dj., str. 77. - 88.

25 Kujundžić je svoje slovno rješenje za slogotvorno $r$ obrazložio u predgovoru Marijanovićevoj latinskoj gramatici: „Vishe puta, kadase A pria R metne, a josh slidi koje neglasovito slovo, ondase izgovara neshto polak megju A i E, i za ovo zlamenovati odpotrebeje nad ono $\ddot{A}$ dva puncta (ä) metnuti (: signum diacritucum:) jerbochese po ovi naçin shtiocz opomenuti, dase ima drugaçie izgovarati, nego u naravnom svomu stanju" S. MARIJANović, Institutiones ... str. XIII. 
$i j e .{ }^{26} \mathrm{U}$ sutješkome su kraju hiperjekavizmi bili rezultat utjecaja pretjerano ijekavskih govora.

Tablično su prikazana slovna rješenja Stjepana Vilova (1736.) kao predstavnika franjevaca budimskoga kruga, Kujundžić-Marijanovićeva lipopisanja (1822.) i Ambroza Matića u Knjixici (1832.). ${ }^{27}$

Tablica 1. Slovopis S. Vilov - A. Kujundžić i S. Marijanović - A. Matić

\begin{tabular}{|l|l|l|l|}
\hline Fonem & $\begin{array}{l}\text { Stjepan } \\
\text { Vilov (1736.) }\end{array}$ & $\begin{array}{l}\text { Kujundžić- } \\
\text { Marijanovićevo } \\
\text { lipopisanje (1822.) }\end{array}$ & $\begin{array}{l}\text { Ambroz Matić } \\
\text { (Knjixica, 1832.) }\end{array}$ \\
\hline$/ c /$ & $c$ & $c / c z$ & $c$ \\
\hline$/ c ̌ /$ & $c s$ & $c ̧$ & $c ̧ / c s$ \\
\hline$/ c ́ /$ & $c h$ & $c h$ & $c h$ \\
\hline$/ \check{\zeta} /$ & $c x$ & $c x$ & $c x$ \\
\hline$/ \zeta^{\prime} /$ & $g j$ & $g / g j / d j$ & $g j / d j / j$ \\
\hline$/ ! /$ & $l j$ & $l j$ & $l j$ \\
\hline$/ n /$ & $n j$ & $n j$ & $n j$ \\
\hline$/ r /$ & $\ddot{a} /$ & $e r$ \\
\hline$/ s /$ & $e r$ & $s$ & $s / \int / \iint$ \\
\hline$/ \check{s} /$ & $s$ & $s h$ & $s h$ \\
\hline$/ \check{z} /$ & $s s$ & $x$ & $x$ \\
\hline & $x$ & & \\
\hline
\end{tabular}

\section{Zaključak}

Knjixica je Ambroza Matića sadržajno oblikovana kao dopuna Marijanovićevoj gramatici, što je čini jedinstvenom među hrvatskim preradbama Grigelyeve latinske gramatike čiji su autori bili bosanski franjevci u 19. st. U tome je nizu prva gramatika koja ima naslov na hrvatskome jeziku.

26 Vidi Dalibor Brozović, „Izvještaj o dijalektološkim istraživanjima u srednjoj Bosni (okolica Kraljeve Sutjeske i Vareša i lijeva obala Krivaje)“, Ljetopis JAZU, Zagreb, knj. 65., 1961., 337. i Ivo PranjKović, Hrvatski jezik i franjevci Bosne Srebrene, MH Zagreb, Zagreb, 20oo., str. 48 .

${ }^{27}$ Navedeni su samo oni primjeri koji su se pisali drukčije u odnosu na današnju latinicu. 
Da bi autor mogao pripremiti dopunu jednomu priručniku/udžbeniku, morao je dobro poznavati njegov sadržaj, a iz pragmatično-metodičkih razloga slijediti slovopis i nazivlje te biranim primjerima obogatiti određene dijelove čije je usvajanje učenicima trebalo olakšati i pojednostaviti. Matićeva se dopuna odnosi na dio morfologije. Kratka pravila prate nizovi dvojezičnih primjera. Pragmatični su razlozi zahtijevali da autor primijeni i zavičajno načelo te je među primjerima naveo domaće toponime i etnonime. Gramatički nazivi, koji su ograničeni na dio morfologije, pokazuju da je Matić pri izboru slijedio tradiciju svojih prethodnika, prerađivača Grigelyeve gramatike. Vjerojatno je predavačka praksa potaknula autora da po ugledu na Grigelya izabere formu stiha da bi učenici lakše i brže mogli pamtiti pravila. U slovopisnome inventaru jedino se pisanje fonema / $\check{c} /$, slogotvornoga $\mathrm{r}$ i ponegdje fonema /s/ razlikuje od Kujundžić-Marijanovićeva lipopisanja. Svojim je leksičkim izborom hrvatskih prijevodnih elemenata u oprimjerivanju pravila birao domaće izvedenice i višečlana rješenja te time ukazao na tvorbene mogućnosti hrvatskoga jezika i njegova bogaćenja. Temeljna je zadaća ovoga priručnika bila upotpuniti drugu gramatiku kojom su se služili učenici gramatičke škole, zbog čega ju je autor i naslovio ručnom knjižicom. Hrvatskoga teksta u njoj nema mnogo, ali dostatno da nam gramatičko nazivlje, jezične i slovopisne posebnosti ukažu da je riječ o nastavljaču franjevačkoga jezičnog uzusa koji je slijedio svoju subraću u pisanju gramatika. Knjixica je bila važna za kontinuitet pisanja gramatika (ne samo latinskoga jezika) na hrvatskome jeziku u BiH u 19. st., za čuvanje i razvoj hrvatskoga gramatičkog nazivlja, bogaćenje leksika, učvršćivanje hrvatskoga kao metajezika te općenito za opis njegova razvoja. Bez obzira na to što je riječ o gramatikama stranoga jezika namijenjenim obrazovanju svećeničkoga podmlatka, takvi su priručnici definicijama, pravilima o hrvatskoj gramatici te implicitnim jezičnim činjenicama omogućavali usvajanje i hrvatske gramatike. 


\section{Literatura}

- Alighieri, Dante, Nauk o pučkom jeziku - De vulgari lingua, Institut za hrvatski jezik i jezikoslovlje, Zagreb, 1998.

- Baвić, Tomo, Prima grammaticae institutio pro tyronibus Illyricis accomodata, Venecija, 1712.

- Borić, MARIJANA, „Hrvatski aritmetički udžbenik Ambroza Matića iz 1827. za gramatičke škole u Bosni“, Zbornik o Petru Bakuli, Hrvatski studiji Sveučilišta u Zagrebu, Zagreb, 2013., str. 449. 462.

- Brozović, DALIBor, „Izvještaj o dijalektološkim istraživanjima u srednjoj Bosni (okolica Kraljeve Sutjeske i Vareša i lijeva obala Krivaje)“, Ljetopis JAZU, Zagreb, knj. 65., 1961., str. 334. - 350.

- Dukat, Vladoje, „Hrvatske preradbe Grigelyevih Institutiones Grammaticae", Rad JAZU, Zagreb, knj. 172., 1908., str. 1. - 100.

- Jembrin, Alojz, „Tomaš Mikloušić i njegovo djelo“, Hrvatsko zagorje, Krapina, god. viI. (2001.) br. 2., str. 5. - 21.

- Jembrih, Alojz, "Gramatičko nazivlje i leksička polivalencija u Mikloušićevu Syllabusu (1817.)“, Kaj, Zagreb, god. LI. (2018.) br. 1. -2 ., str. 41. -53 .

- Knezović, Pavao, „Njegovanje hrvatskog u gramatikama latinskog jezika (17. i 18. st.)“, Hrvatski jezik u Bosni i Hercegovini jučer $i$ danas, Pedagoški fakultet Sveučilišta u Mostaru, Mostar, 2002., str. 53. -69 .

- Marijanović, StjePan, Institutiones grammaticae latinae idiomate illyrico propositae ac ad usum iuventutis Provinciae Bosnae Argentinae compilatae ..., Split, 1822.

- Marijanović, Stjepan, Syntaxis linguae latinae iuventuti Provinciae Bosnae Argentinae accomodata, Apud Andream filiumque Santini, Venecija, 1823. 
- Marjanović, Mirko, Leksikon hrvatskih književnika Bosne $i$ Hercegovine od najstarijih vremena do danas, MH Sarajevo HKD Napredak Sarajevo, Sarajevo, 2001.

- Pranjković, Ivo, Hrvatski jezik i franjevci Bosne Srebrene, MH Zagreb, Zagreb, 2000.

- Pranjković, Ivo, Franjevačko spisateljstvo na hrvatskome jeziku, Hrvatska sveučilišna naklada, Zagreb, 2008.

- RaguŽ, Dragutin, „Hrvatska gramatička terminologija u dvjema preradbama Alvaresove latinske gramatike“, Filologija, Zagreb, br. 10., 1981., str. 97. - 125.

- Rječnik hrvatskoga ili srpskoga jezika, sv. I. - XXIII., JAZU, Zagreb, 1880. - 1976.

- SAmARdžIja, Marko, „Doprinos budimskoga franjevačkog kruga oblikovanju tzv. slavonskoga slovopisa", Iz triju stoljeća hrvatskoga standardnog jezika, Hrvatska sveučilišna naklada, Zagreb, 2004., str. 14. - 19.

- Tafra, Branka - Mateljak, Anela, „Mjesto Šitovićeve gramatike u povijesti hrvatskoga jezikoslovlja", Zbornik o Lovri Šitoviću, Hrvatski studiji Sveučilišta u Zagrebu, Zagreb, 2009., str. 111. 129.

- Šitović, Lovro, Grammatica Latino- Illyrica ex Emmanuelis aliorumque approbatorum grammaticorum libris, iuventuti Illyricae studiose accommodata, Venecija, 1713.

- Valent, AnĐA -Vuković, IvicA, „Računica fra Ambroza Matića: začeci metodike nastave matematike u Hrvata", Bosna franciscana, Sarajevo, god. xxIII. (2015.) br. 42., str. 95. - 109. 
Original scientific paper

Received on October 22, 2019

Katica Krešić

University of Mostar, Faculty of Humanities and Social Sciences

\section{GRAMMAR BY AMBROZ MATIC (1832)}

\section{Abstract}

In 1832, a Latin grammar book Knjixica Rucsna was published in Osijek by the Bosnian Franciscan Ambroz Matic. Ambroz Matic taught Latin and mathematics in Kraljeva Sutjeska and, for teaching purposes, he compiled an arithmetic and a Latin grammar textbook written in Croatian. The paper studies the content concept of Knjixica as pragmatic amendments to Marijanovic's Latin grammar. The Croatian text analyzes the spelling and grammatical terminology while it singles out some translational lexical solutions that did not take remain in the Croatian language.

Keywords: Latin grammar; Croatian language; Ambroz Matic; spelling; grammatical terminology 